\title{
Nearly zero energy renovation concepts for apartment buildings
}

\author{
Kalle Kuusk ${ }^{1}$, Jens Naumann ${ }^{2}$, Annina Gritzki ${ }^{2}$, Clemens Felsmann ${ }^{2}$, Michele De Carli ${ }^{3}$, Massimo Tonon ${ }^{3}$, Jarek \\ Kurnitski ${ }^{1,4}$ \\ ${ }^{1}$ Tallinn University of Technology, Estonia \\ ${ }^{2}$ TU Dresden, Germany \\ ${ }^{3}$ Padua University, Italy \\ ${ }^{4}$ Aalto University, Finland
}

\begin{abstract}
Revised EPBD directive has set ambitious targets for renovation. It is stated that Member States shall establish a long-term strategy facilitating the cost-effective transformation of existing buildings into nearly-zero energy buildings. The long-term strategy should set out a roadmap with a view to the long-term 2050 goal of reducing greenhouse gas emissions in the European Union. This creates the need for cost-efficient renovation solutions which can be implemented in large scale. The impact assessment shows that roughly a doubled renovation rate of $3 \%$ would be needed to accomplish the energy efficiency ambitions in a cost-effective manner. The objective of this study is to specify renovation concepts with adequate heating and ventilation, based on Estonian and German apartment buildings and corresponding local solutions. Energy performance and sizing analyses were conducted for selected multifamily apartment buildings typical for 1960-70es with three different renovation concepts. Energy calculations were conducted with national energy calculation methods and national energy requirements for major renovation. In the renovation, the building envelope insulation, air tightness, and heating and ventilation systems were improved so that the renovated building complies with national nearly zero-energy requirement for major renovation.
\end{abstract}

\section{Introduction}

Revised Energy Performance of Buildings Directive [1] has set targets for renovation including establishing a long-term strategy facilitating the cost-effective transformation of existing buildings into nearly-zero energy buildings. The long-term strategy should set out a roadmap with a view to the long-term 2050 goal of reducing greenhouse gas emissions in the EU by $80-95 \%$ compared to 1990. This creates the need for cost-efficient renovation solutions which can be implemented in large scale.

Study [2] conducted about the results obtained from the application of a cost-optimal calculation method for identifying proper retrofit measures to reach cost-optimal renovation levels found that the energy saving potential of retrofit cost-optimal targets are very relevant (36-88\% in term of net primary energy). Same study also concluded that cost-optimal analyses of energy efficiency measures of buildings are mainly based on the different envelope insulation solutions and the selection of heating generators. Analysis of the strategy for the energy renovation of the housing stock in Spain concluded that the priority should be the insulation envelope of the building. Once the highest possible savings are obtained by improving the envelope, then the strategies to improve the heating and cooling systems should be addressed [3]. IEA EBC Annex 56 concluded that when the target is to reduce the carbon emissions, it is advisable to use renewable energies in addition to the energy saving measures because renewable energies reduce the emissions in a more cost-effective way [4].

Although the renovation of apartment buildings has been the subject of many studies, there has some aspects which are not usually represented in the researches. Literature review on renovation of multifamily buildings found that researches have mainly energy focus and other aspects of renovation may not be strongly represented. One of these subjects are different ventilation solutions [5].

The objective of this study is to specify renovation concepts with adequate heating and ventilation as well as overheating prevention or cooling solutions in three European climates from North to South, based on Estonian, German and Italian apartment buildings and corresponding local solutions. The renovation concepts should fulfil the energy requirements set by local authorities for major renovation. As buildings become well insulated and airtight, the need for heating decreases but the need for cooling increases. Insulation of building envelope and replacement of old leaky windows can also result in poor indoor air quality, unless the ventilation

* Corresponding author: kalle.kuusk@taltech.ee 
systems are upgraded as well. Possible options for ventilation upgrade are air handling units with heat recovery or heat pump from the exhaust air, often referred to as exhaust air heat pump.

\section{Methods}

\subsection{Renovation concepts}

Energy calculations were done for the three renovation concepts.

\subsubsection{Concept 1 (C1)}

Concept 1 uses central mechanical exhaust ventilation with exhaust air heat pump and ventilation radiators for heating. Ventilation radiator combines ventilation air supply with a hydronic radiator: outdoor air enters a room through a wall channel with a filter and moves through radiator panels where air is pre-heated to room air temperature. Heat outputs of ventilation radiators are high and thereby the design temperatures can be low: the flow/return temperatures may be $45 / 35^{\circ} \mathrm{C}$. The energy source of the heat pump (ventilation extract air from apartments) is year-round even at room temperature. All these factors create the conditions for the high level of heat pump COP. Working principle of concept 1 is shown in Fig. 1.

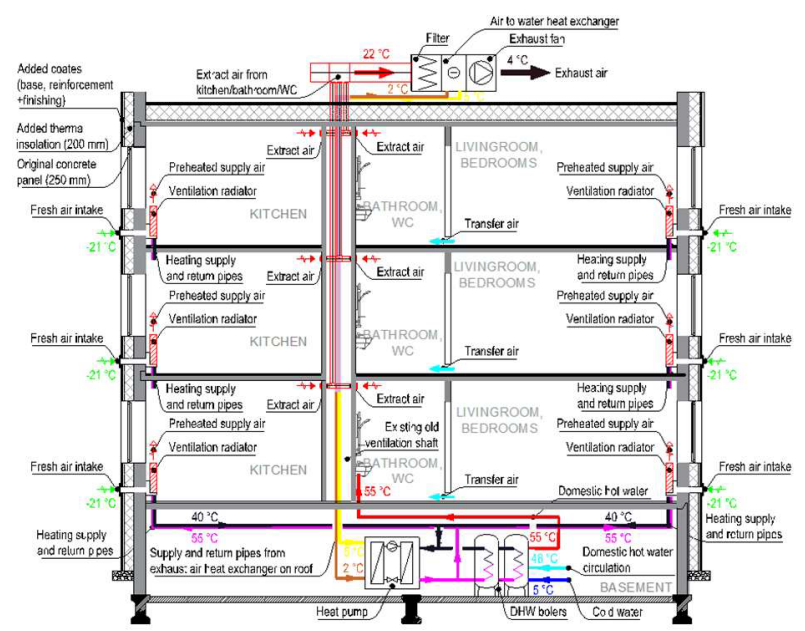

Fig. 1. Working principle of mechanical exhaust ventilation system with heat pump for heat recovery.

\subsubsection{Concept 2 (C2)}

Concept 2 (C2) uses fan coil units in apartments for heating and cooling. Otherwise the principles of the system are similar to the Concept 1: central mechanical exhaust ventilation and exhaust air heat pump with cooling function. Fresh outdoor air enters through intake air vents. Photovoltaic system for on-site renewable energy production is used to compensate additional electricity use for cooling.

\subsubsection{Concept 3 (C3)}

Concept C3 uses centralized supply and exhaust ventilation system with heat recovery. Ventilation ductwork is installed to the insulation layer. Gas boiler (DE and IT) or district heating (EE) are used as heat source. In this concept, geothermal and outdoor air heat pumps could also be used, but the heat pump COP will not reach the same level as exhaust air heat pumps in Concept C1. This is due to the lower heat source temperatures and slightly higher radiator water temperatures: typical design flow/return temperatures are around $50 / 40^{\circ} \mathrm{C}$.

In all concepts, ventilation rates comply with new building requirements.

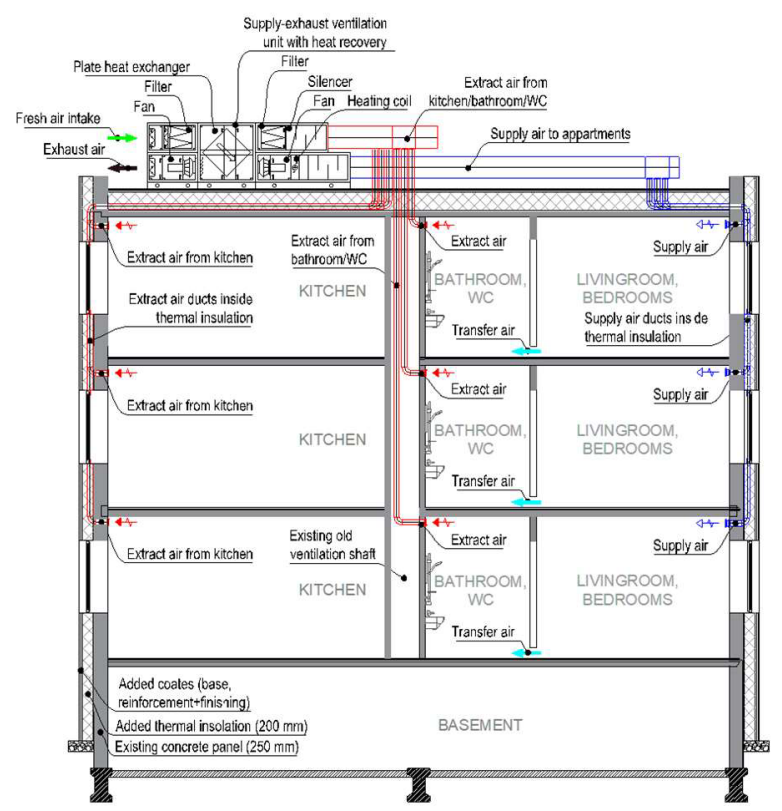

Fig. 2. Working principle of central air handling unit with heat recovery.

\subsection{Calculations with national methodologies}

As a first step, the energy calculations were done for typical apartment buildings in each country: Estonia (EE), Germany (DE) and Italy (IT). The results are reported as primary energy use per heated floor area and year $\left(\mathrm{kWh} /\left(\mathrm{m}^{2} \mathrm{a}\right)\right)$. Results are calculated with national calculations methodologies and with standardized primary energy factors. Unified primary energy factors are used to avoid the differences in calculation results due to the different primary energy factors. Energy calculations include the annual energy use for space heating, cooling, ventilation, domestic hot water and the auxiliary electricity use of these technical systems.

Characteristics of the typical apartment buildings are given in Tables 1 and 2 . 
Table 1. Characteristics of the typical apartment buildings.

\begin{tabular}{lccc} 
& EE & DE & IT \\
\hline Construction year & 1966 & $1958 \ldots 68$ & 1966 \\
Number of floors & 5 & 4 & 4 \\
${\text { Net floor area, } \mathrm{m}^{2}}_{\text {Heated area, }^{2}}^{3519}$ & 3101 & 1411 \\
Number of apartments $^{2}$ & 2968 & 2819 & 1303 \\
\hline
\end{tabular}

Table 2. Thermal transmittance of the building envelope before the renovation.

\begin{tabular}{lccc}
$\begin{array}{l}\text { Thermal transmittance, } \\
\mathrm{W} /\left(\mathrm{m}^{2} \mathrm{~K}\right)\end{array}$ & EE & DE & IT \\
\hline External wall & 0.9 & 1.2 & 1.34 \\
Roof or attic & 0.8 & 0.51 & 1.45 \\
Windows & 2.0 & 3.0 & 5.6 \\
Basement ceiling & 0.6 & 1.08 & - \\
\hline
\end{tabular}

Energy calculations were done with IDA Indoor Climate and Energy 4.8 (IDA-ICE) in Estonia, with Hottgenroth Energieberater 18599 3D in Germany and with Edilclima v9.19.35 in Italy. IDA-ICE is an hourly based simulation tool, calculation tools used in Germany and Italy are based on monthly energy balance.
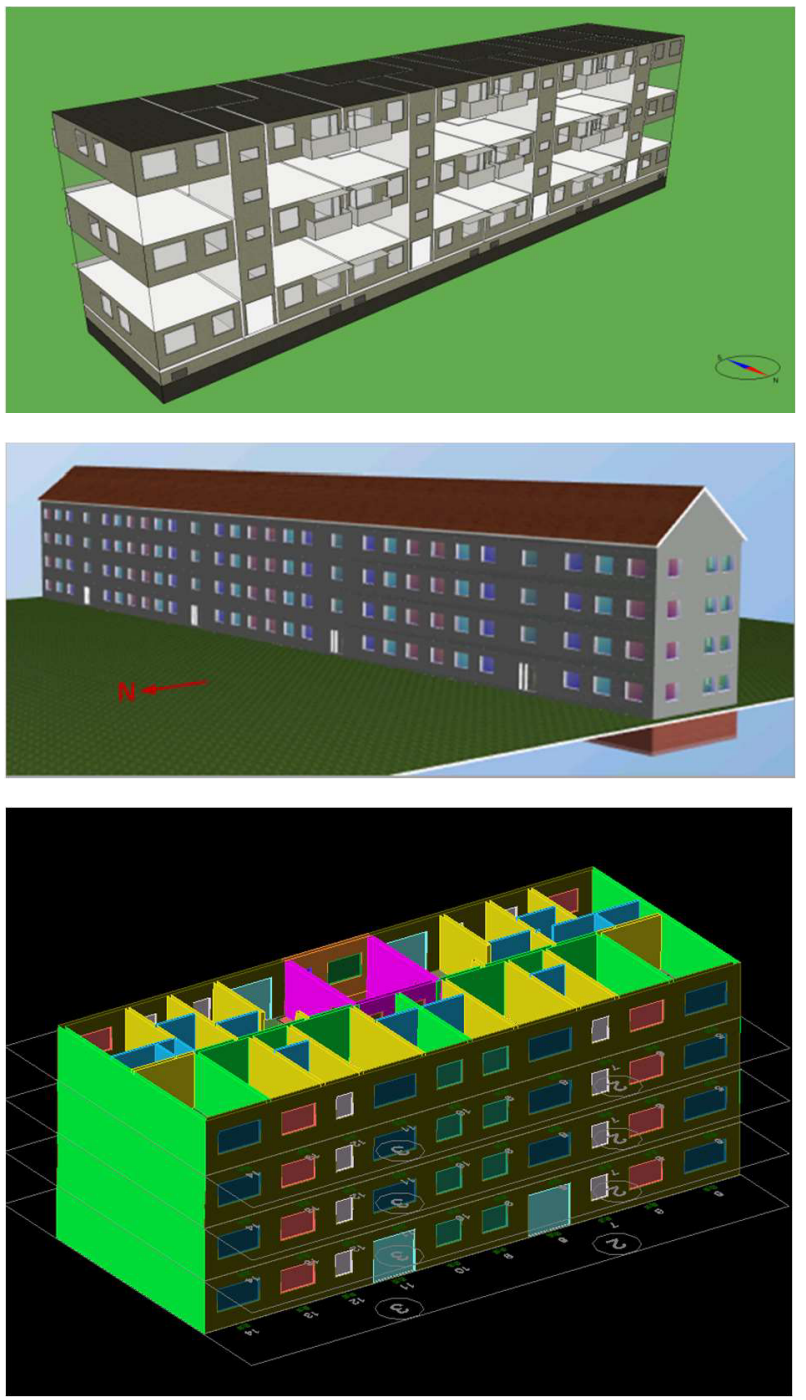

Fig. 3. View of the national reference buildings simulation models (above EE, centre DE, below IT).

In the renovation, the building envelope insulation, air tightness, and heating and ventilation systems were improved so that the renovated building complies with national nearly zero energy requirements for major renovation. Depending on the national definition, the permissible primary energy demand of this standard is more or less far from zero.

Table 3. Thermal transmittance of the building envelope after the renovation.

\begin{tabular}{lccc}
$\begin{array}{l}\text { Thermal transmittance, } \\
\mathrm{W} /\left(\mathrm{m}^{2} \mathrm{~K}\right)\end{array}$ & EE & DE & IT \\
\hline External wall & 0.15 & 0.26 & 0.21 \\
Roof or attic & 0.1 & 0.2 & 0.18 \\
Windows & 1.1 & 1.3 & 1.4 \\
Basement ceiling & 0.6 & 0.34 & - \\
\hline
\end{tabular}

Energy simulations for the renovation solutions were done with national standard use conditions.

Table 4. National standard use conditions for energy calculations.

\begin{tabular}{lccc} 
& EE & DE & IT \\
\hline Ventilation airflow, $1 / \mathrm{h}$ & 0.6 & 0.4 & 0.5 \\
Heating setpoint, ${ }^{\circ} \mathrm{C}$ & 21 & 20 & 20 \\
Cooling setpoint, ${ }^{\circ} \mathrm{C}$ & 27 & 25 & 26 \\
${\text { Internal gains, } \mathrm{W} / \mathrm{m}^{2}}^{2}$ & 4.4 & 3.75 & 3.75 \\
DHW, $\mathrm{kWh} /\left(\mathrm{m}^{2} \mathrm{a}\right)$ & 30 & 13.8 & 26 \\
\hline
\end{tabular}

All renovation cases in Italy include installation of 8.4 $\mathrm{kWh}$ of PV-panels as it is required by the regulations (installed $\mathrm{kW}=$ footprint area of the building / 50).

The same primary energy factors, 2.0 for the electricity and 1.0 for gas and district heat, have been used in all countries to keep the results comparable.

\subsection{Energy simulations with standardized input data and methodology}

As a second step, the energy simulations were done for all climate zones with a single apartment building and with standardized input data for standard conditions. Apartment building from Germany was chosen for this case study. Energy calculations were done with IDA Indoor Climate and Energy (IDA-ICE) simulation software.

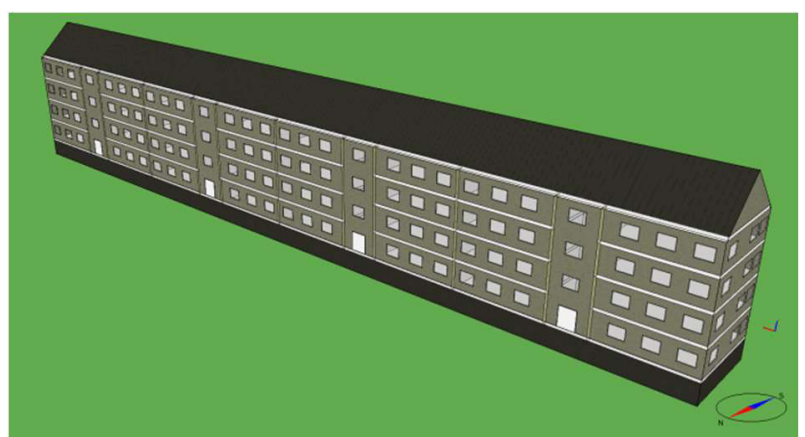


Fig. 4. View of the building simulation model.

Energy calculations were done for three locations with three different climate files:

- $\quad$ Estonia $\rightarrow$ Estonian TRY

- $\quad$ Germany $\rightarrow$ TRY2015_523938130651_Jahr

- $\quad$ Italy $\rightarrow$ Milano Linate TRY

Characteristics of the building envelope and supply systems used in energy simulations for this case study are given in Tables 5 and 6.

Table 5. Characteristics of the building envelope.

\begin{tabular}{lccc} 
Building envelope & EE & DE & IT \\
\hline Thermal transmittance, $\mathrm{W} /\left(\mathrm{m}^{2} \mathrm{~K}\right)$ & & & \\
External walls & 0.15 & 0.26 & 0.21 \\
Windows & 1.10 & 1.3 & 1.4 \\
Attic floor & 0.11 & 0.2 & 0.18 \\
Basement ceiling & 0.6 & 0.34 & 1 \\
\hline Airtightness $\mathrm{q} 50, \mathrm{~m}^{3} /\left(\mathrm{h} \cdot \mathrm{m}^{2}\right)$ & 3.0 & 3.0 & 3.0 \\
\hline Linear thermal transmittance, $\mathrm{W} /(\mathrm{mK})$ & & \\
External wall - external wall & 0.15 & 0.15 & 0.15 \\
Roof - external wall & 0.2 & 0.2 & 0.2 \\
Window - external wall & 0.05 & 0.1 & 0.1 \\
External wall - internal wall & 0.01 & 0.01 & 0.01 \\
External wall - internal slab & 0.01 & 0.01 & 0.01 \\
External wall - external slab & 0.5 & 0.5 & 0.5 \\
\hline
\end{tabular}

Table 6. Characteristics of the supply systems.

Service systems

\begin{tabular}{cc}
\hline Heat recovery temperature ratio of AHU & 0.8 \\
Minimum allowed exhaust air temperature, ${ }^{\circ} \mathrm{C}$ & 5 \\
\hline Specific Fan Power (SFP), $\mathrm{kW} /\left(\mathrm{m}^{3} / \mathrm{s}\right):$ \\
Central air handling unit & 1.8 \\
Exhaust ventilation with fancoils & 1.5 \\
Exhaust ventilation & 1.2 \\
\hline Exhaust air heat pump SCOP: & \\
Estonia (heating/DHW/cooling) & $3.5 / 3.0 / 3.0$ \\
Germany (heating/DHW/cooling) & $3.9 / 3.9 / 3.0$ \\
Italy (heating/DHW/cooling) & $4.0 / 4.0 / 3.0$ \\
\hline PV-panels, $\mathrm{kW} \quad$ Estonia \\
\multicolumn{2}{c}{10} \\
Germany \\
Italy & 12 \\
\hline
\end{tabular}

* Minimum temperature of exhaust air (air from the ventilation unit) is limited reducing the temperature ratio at low outdoor temperatures to prevent the heat exchanger from freezing.

PV systems are used with all renovation concepts in Italy where it is required by regulation. PV is also needed in concept with cooling in Germany and Estonia in order to comply with major renovation requirements.

Standard use input data is based on the EN 16798$1: 2019$ [6].

Table 7. Standard use input data.

\begin{tabular}{lc} 
& EN 16798 \\
\hline Occupant, $\mathrm{m}^{2} /$ person & 28.3 \\
Appliances, $\mathrm{W} / \mathrm{m}^{2}$ & 3.0 \\
Lighting, $\mathrm{W} / \mathrm{m}^{2}$ & 9.0 \\
Usage time & $0: 00-24: 00$ \\
Ventilation operation hour & $0: 00-24: 00$ \\
Lighting usages rate & 0.14
\end{tabular}

Occupancy usages rate $\quad 0.6$

Appliance usages rate $\quad 0.6$

Domestic hot water use, $\mathrm{kWh} / \mathrm{m}^{2}$ a $\quad 25$

Ventilation rate, $1 / \mathrm{m}^{2} \mathrm{~s} \quad 0.5$

Heating set point, ${ }^{\circ} \mathrm{C} \quad 20$

Cooling set point, ${ }^{\circ} \mathrm{C} \quad 26$

Boiler efficiency, gas boiler $\quad 0.95$

Boiler efficiency, district heating $\quad 1.0$

Distribution \& emission efficiency $\quad 0.91$

Circulation pump, $\mathrm{kWh} /\left(\mathrm{m}^{2} \mathrm{a}\right) \quad 2.0$

Weighting factor for electricity $\quad 2.0$

Weighting factor for heating energy $\quad 1.0$

\section{Results}

\subsection{Calculations with national methodologies}

The primary energy values include the annual energy use for space heating, cooling, ventilation, domestic hot water and the auxiliary electricity use of these technical systems.

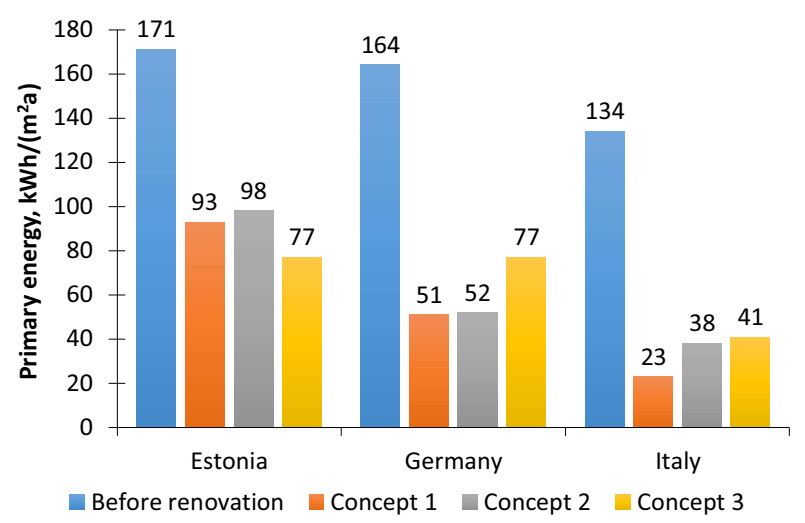

Fig. 5. Primary energy values calculated with national methodologies.

In Estonia, the major renovation requirement is Energy Performance Certificate (EPC) class C. The best result is achieved with central heat recovery ventilation leading to EPC class B. The exhaust air heat pump concept with ventilation radiators just fulfils the requirement. Adding the cooling function to exhaust air heat pump concept with fan coils needs a small PV system to compensate the additional electricity use for cooling in order to achieve the energy efficiency requirement.

In Germany, all three concepts fulfil the requirements for major renovation, corresponding to energy performance certificate (EPC) class C. The concepts with exhaust air heat pump, both with ventilation radiators and fan coils, result in EPC class A+, which is even slightly better than NZEB requirement for new buildings. The concept with central heat recovery ventilation results in EPC class $\mathrm{C}$, which still meets the requirements for major renovation.

In Italy, major renovation requirements are not given with EPC scale, but U-values, heating and cooling energy need, primary energy, renewable energy contribution and installation of PV system requirements are to be satisfied. 
All studied concepts well satisfy these requirements for major renovation, but small PV systems must be added in order to fulfil the minimum amount of renewable energy and the specific requirement of PV installation.

\subsection{Energy simulations with standardized input data and methodology}

Energy simulation results (Figure 6 and Table 8) with standardized input data and methodology shows somewhat different trends than calculation results with national methodologies. In Germany and Italy, renovation concept with central heat recovery ventilation (C3) shows almost the same primary energy use as renovation concepts with exhaust air heat pump $\mathrm{C} 1$. Calculations with national calculation methodologies resulted in significantly lower primary energy for the exhaust air heat pump solutions.

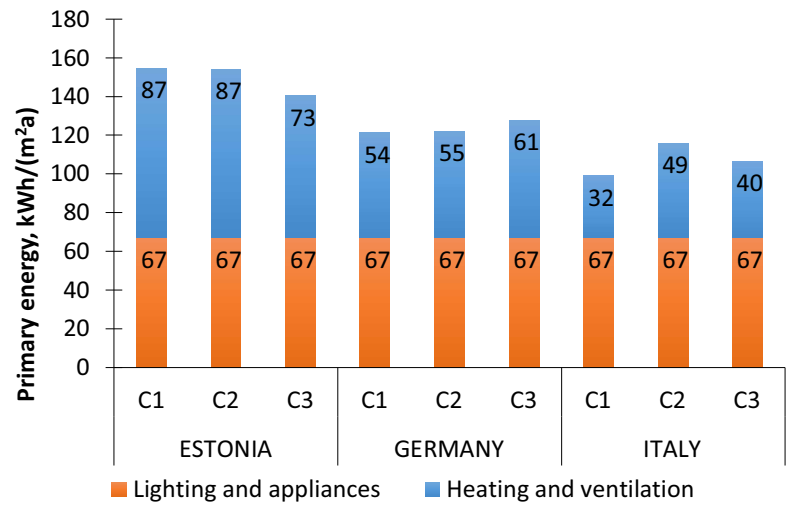

Fig. 6. Primary energy values calculated with standardized methodologies.

Table 8. Energy simulation results with standardized methodology.

\begin{tabular}{|c|c|c|c|c|c|c|c|c|c|}
\hline & \multicolumn{3}{|c|}{ ESTONIA } & \multicolumn{3}{|c|}{ GERMANY } & \multicolumn{3}{|c|}{ ITALY } \\
\hline & $\mathrm{C} 1$ & $\mathrm{C} 2$ & $\mathrm{C} 3$ & $\mathrm{C} 1$ & $\mathrm{C} 2$ & $\mathrm{C} 3$ & $\mathrm{C} 1$ & $\mathrm{C} 2$ & $\mathrm{C} 3$ \\
\hline Heat for space and ventilation heating & 14 & 14 & 26 & & & 14 & & & 8 \\
\hline Electricity for space and ventilation heating & 19 & 19 & & 13 & 13 & & 9 & 9 & \\
\hline Heat for DHW heating & 5 & 5 & 27 & & & 27 & & & 27 \\
\hline Electricity for DHW heating & 8 & 8 & & 7 & 7 & & 7 & 7 & \\
\hline Electricity for cooling & & 1 & & & 3 & & & 7 & \\
\hline Auxiliary electricity (fans and pumps) & 7 & 9 & 10 & 7 & 9 & 10 & 7 & 9 & 10 \\
\hline Electricity for lighting and appliances & 34 & 34 & 34 & 34 & 34 & 34 & 34 & 34 & 34 \\
\hline Electricity from PV-panels & & -3 & & & -4 & & -8 & -8 & -8 \\
\hline Delivered energy, $\mathrm{kWh} /\left(\mathrm{m}^{2} \mathrm{a}\right)$ & 87 & 86 & 97 & 61 & 61 & 85 & 50 & 58 & 71 \\
\hline Primary energy, $\mathrm{kWh} /\left(\mathrm{m}^{2} \mathrm{a}\right)$ & 155 & 154 & 141 & 121 & 122 & 128 & 99 & 116 & 107 \\
\hline $\begin{array}{l}\text { Primary energy } w / o \text { lighting and appliances, } \\
\mathrm{kWh} /\left(\mathrm{m}^{2} \mathrm{a}\right)\end{array}$ & 87 & 87 & 73 & 54 & 55 & 61 & 32 & 49 & 40 \\
\hline
\end{tabular}

Comparison of the national calculations and the energy simulations of the case study with input data from EN 16798-1:2019 reveals that there is no uniform trend how national calculations and standardized calculations give different results.

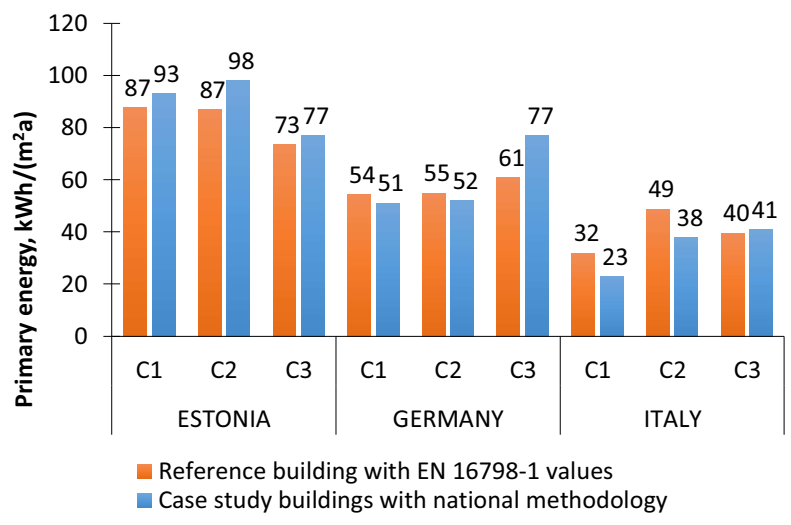

Fig. 7. Comparison of the calculation results.
Comparison of the calculation results with the Estonian national calculation results shows the same trend with both calculation methodologies. Renovation concept with central air handling unit for heat recovery have the

best energy efficiency results. Minor differences between calculation results are caused by the heating setpoint which is $21^{\circ} \mathrm{C}$ in Estonian calculation methodology and $20{ }^{\circ} \mathrm{C}$ in $\mathrm{EN} 16798$, and by differences in internal gains. In Estonian calculation methodology internal heat gains from lighting are $8 \mathrm{~W} / \mathrm{m}^{2}$ and usage rate 0.1 . Corresponding numbers in the EN 16798 are $9 \mathrm{~W} / \mathrm{m}^{2}$ and 0.14 .

Comparison of the calculation results with the German national calculation results shows the biggest difference for the renovation concept with central air handling unit for heat recovery (C3). Differences are mainly caused by the ventilation airflow rates, infiltration and internal gains.

Ventilation and infiltration airflow rates are considered together in German national calculation methodology and heat losses through infiltration are 
included to the ventilation heat losses. There are 4 categories for the building airtightness in the German national calculation methodology. The category is based on the building type and the building size. Category II was used in national calculations with $\mathrm{n} 50=3.441 / \mathrm{h}$ (derived from $\mathrm{q}_{50}=6 \mathrm{~m}^{3} /\left(\mathrm{hm}^{2}\right)$ ). For category II the airtightness is similar to that of a new building, but without a blower door test. Under normal pressure conditions, the $\mathrm{n} 50$ value $3.44 \mathrm{1} / \mathrm{h}$ for infiltration results in an air change of $0.32 \mathrm{l} / \mathrm{h}$. This high infiltration air change makes heat recovery ventilation ineffective that explains an outlier primary energy value of $77 \mathrm{kWh} /\left(\mathrm{m}^{2} \mathrm{a}\right)$ calculated with national methodology. In simulations with standardized methodology, twice lower building leakage rate value of $\mathrm{q} 50=3 \mathrm{~m}^{3} /\left(\mathrm{hm}^{2}\right)$ was used.

Ventilation airflow rate according to German national methodology is $0.41 / \mathrm{h}$ which in the case study correspond to $0.3 \mathrm{l} /\left(\mathrm{sm}^{2}\right)$. Ventilation airflow rate according to $\mathrm{EN}$ 16798 is $0.51 /\left(\mathrm{sm}^{2}\right)$ which in the case study correspond to $0.661 / \mathrm{h}$.

Internal gains in German national methodology are lower than in EN $16798,3.75 \mathrm{~W} / \mathrm{m}^{2}$ and $4.86 \mathrm{~W} / \mathrm{m}^{2}$ respectively.

Comparison of the calculation results with the Italian national calculation results shows the biggest difference for the renovation concepts with exhaust air heat pumps. Differences are mainly caused by the ventilation airflow rates and auxiliary energy.

Ventilation airflow rate according to Italian national methodology is $0.51 / \mathrm{h}$ which in the case study correspond to $0.38 \mathrm{l} /\left(\mathrm{sm}^{2}\right)$. Ventilation airflow rate according to EN 16798 is $0.51 /\left(\mathrm{sm}^{2}\right)$ which in the case study correspond to $0.661 / \mathrm{h}$.

Energy use for circulation pumps and ventilation fans for the investigated building according to Italian national methodology is $0.6 \mathrm{kWh} /\left(\mathrm{m}^{2} \mathrm{a}\right)$ and $1.1 \mathrm{kWh} /\left(\mathrm{m}^{2} \mathrm{a}\right)$ respectively. Energy use for circulation pumps according to EN 16798 is $2.0 \mathrm{kWh} /\left(\mathrm{m}^{2} \mathrm{a}\right)$. Energy use for ventilation fans with SFP $1.2 \mathrm{~kW} /\left(\mathrm{m}^{3} / \mathrm{s}\right)$ and ventilation airflow rate $1700 \mathrm{l} / \mathrm{s}$ is $5.4 \mathrm{kWh} /\left(\mathrm{m}^{2} \mathrm{a}\right)$.

\section{Discussion}

Results of the study correspond with other research findings which suggest that selection of renovation concepts depends mainly on regulations [7]. That makes comparison of the renovation solutions between the countries difficult. Previous researches have shown that national nZEB values are challenging to be compared because of differences in primary energy factors, energy flows included and calculation input data [8].

Comparison of the different calculation methodologies showed some interesting findings. In relatively simple residential buildings, simplified and detailed calculations can have same results. For example, the thermal bridges in hourly energy simulations were taken into account with the linear thermal transmittance and the length of the thermal bridge. In German national methodology the thermal bridges are taken account with the increase of the U-value of all components of the building envelope continuously by $0.05 \mathrm{~W} /\left(\mathrm{m}^{2} \mathrm{~K}\right)$. In the case study, both approaches resulted the same annual heat loss through building envelope.

Another example is the energy need of the DHW energy need where EN 16798-1: 2019 approach differ from the German national calculation method. According to EN 16798-1, the DHW net energy need is significantly higher ( 25 vs. $\left.14 \mathrm{kWh} /\left(\mathrm{m}^{2} \mathrm{a}\right)\right)$, but the system losses are significantly lower (4 vs. $15 \mathrm{kWh} /\left(\mathrm{m}^{2} \mathrm{a}\right)$ ). In German national calculation method, the system losses are calculated in detail based on the pipe lengths and insulation of the pipes. In total, both methodologies result in the same heating energy demand for DHW of 29 $\mathrm{kWh} / \mathrm{m}^{2} \mathrm{a}$.

Calculation methodologies can also have impact on the technical solutions suitable for the renovation. In German national methodology the infiltration rate is relatively high and heat losses through infiltration are included to the ventilation heat losses. In the case study the ventilation airflow rate is $0.41 / \mathrm{h}$ and infiltration airflow rate under normal conditions is $0.32 \mathrm{l} / \mathrm{h}$. The total air change rate of the building is $0.721 / \mathrm{h}$. If ventilation air handling unit with heat recovery is considered as a possible renovation solution, only the ventilation airflow of $0.41 / \mathrm{h}(55 \%$ of total air change rate) is covered with heat recovery and the share of ventilation heat losses in energy balance is very high. That makes air handling unit with heat recovery an unattractive renovation solution. In Estonia, the situation is vice versa, as the heat recovery ventilation with low infiltration shows superior performance.

\section{Conclusions}

Practical renovation concepts to old apartment buildings which meet health and renovation nearly zero energy performance requirements were analysed in three different climatic regions of Europe. The calculations were done with national methodologies which made the results not fully comparable due to the differences in calculation methods, input data and climate conditions. Energy simulations with standard input data showed real performance and allowed to draw general conclusions.

In Estonia, the best result is achieved with central heat recovery ventilation. The exhaust air heat pump concept with ventilation radiators just fulfills the requirement. Adding the cooling function to exhaust air heat pump concept with fan coils needs a small PV system to achieve the energy efficiency requirement. Estonian results for all concepts show the same tendencies with both national methodology and energy simulation with standard input data.

In Germany, all three concepts fulfil the requirements for major renovation. The concepts with exhaust air heat pump, both with ventilation radiators and fan coils, are even slightly better than NZEB requirement for new buildings. Heat recovery ventilation calculated with national methodology receives a penalty of high infiltration rate what causes a big deviation from the simulated result.

In Italy, major renovation requirements are not given with EPC scale, but U-values, heating and cooling energy 
need and renewable energy contribution. All studied concepts well satisfy these requirements for major renovation, but small PV systems must be added to all renovation concepts in order to fulfil the requirement of PV installation.

This research was supported by Purmo Group and the Estonian Centre of Excellence in Zero Energy and Resource Efficient Smart Buildings and Districts, ZEBE, (grant No. 20142020.4.01.15-0016) funded by the European Regional Development Fund.

\section{References}

1. The energy performance of buildings Directive (EU) 2018/844 of 30 May 2018.

2. P. Zangheri, R. Armani, M. Pietrobon, L. Pagliano. Identification of cost-optimal and NZEB refurbishment levels for representative climates and building typologies across Europe. Energy Efficiency (2018) 11:337-369

3. B. Serrano-Lanzarote, L. Ortega-Madrigal, A. García-Prieto-Ruiz, L. Soto-Francés, V. M. SotoFrancés. Strategy for the energy renovation of the housing stock in Comunitat Valenciana (Spain). Energy and Buildings 132 (2016) 117-129

4. M. Almeida, M. Ferreira. IEA EBC Annex56 vision for cost effective energy and carbon emissions optimization in building renovation. Energy Procedia 78 (2015) 2409 - 2414

5. A.A. Hamid, K. Farsäter, A. Wahlström, P. Wallentén. Energy \& Buildings 172 (2018) 414-431

6. EN 16798-1:2019 Energy performance of buildings: ventilation for buildings. Indoor environmental input parameters for design and assessment of energy performance of buildings addressing indoor air quality, thermal environment, lightning and acoustics.

7. J. van Oorschot, E. Hofman, J. Halman. Upscaling large scale deep renovation in the Dutch residential sector: a case study. Energy Procedia 96 ( 2016 ) 386 $-403$

8. J. Kurnitski. NZEB requirements in Nordic countries. REHVA Journal - December 2019. 